\title{
Multimodal intervention improves fatigue and quality of life in subjects with progressive multiple sclerosis: a pilot study [Corrigendum]
}

Bisht B, Darling WG, Shivapour ET, et al. Degenerative Neurological and Neuromuscular Disease. 2015;5:19-35.

The authors have recently learnt of a registered copyright for the MS Performance Scales. See Performance Scales, Copyright Registration Number/ Date: TXu000743629/ 1996-04-04; assigned to Delta Quest Foundation, Inc., effective October 1, 2005. ${ }^{1}$ The authors failed to report that Performance Scales $($ is a copyrighted work and is owned by DeltaQuest Foundation. US Copyright law governs the exclusive rights of DeltaQuest Foundation, Inc. to the Performance Scales $\subset$. Under US law a copyrighted work cannot be reproduced in copies, prepared into derivative works, distributed in copies for sale, or displayed to the public without the explicit permission of and/or license from the copyright owner. In addition, reference of original validation study for
Performance Scales by Schwartz et al, ${ }^{2}$ was not provided in the article. To address the issue, we would like to provide correct information to the readers and clarify that copyright of Performance Scales (C) is owned by DeltaQuest Foundation and information regarding Performance Scales $($ can be found in the paper by Schwartz et al. ${ }^{2}$ Authors would also like to clarify that only questions related to fatigue in Performance Scales $(\mathrm{C}$ were used to report fatigue data in the study and were abbreviated as PS-fatigue.

\section{References}

1. Respect of Copyright [webpage on the Internet]. Concord, Massachusetts: DeltaQuest Foundation, Inc. Available from: http://www.deltaquest.org/ pages/copyright.html. Accessed August 12, 2015.

2. Schwartz CE, Vollmer T, Lee H. Reliability and validity of two self-report measures of impairment and disability for MS. North American Research Consortium on Multiple Sclerosis Outcomes Study Group. Neurology. 1999;52(1):63-70.
Degenerative Neurological and Neuromuscular Disease

\section{Publish your work in this journal}

Degenerative Neurological and Neuromuscular Disease is an international, peer-reviewed, open access journal focusing on research into degenerative neurological and neuromuscular disease, identification of therapeutic targets and the optimal use of preventative and integrated treatment interventions to achieve improved outcomes, enhanced

\section{Dovepress}

survival and quality of life for the patient. The manuscript management system is completely online and includes a very quick and fair peer-review system. Visit http://www.dovepress.com/testimonials.php to read real quotes from published authors. 